\title{
Anatomical Studies on Compatibility and Incompatibility of Some Solanaceous Plant Species to Field Dodder (Cuscuta campestris Yuncker)
}

\author{
Awad F. Farah1, Samia M. Ibrahim² \\ ${ }^{1}$ Department of Biology, Faculty of Education, University of Sirt, Sirt, Libya \\ ${ }^{2}$ Department of Science, Faculty of Education, University of Holy Quraan, Omdurman, Sudan \\ Email: awadhfarah@gmail.com, samiafarah78@yahoo.com
}

Received 14 May 2014; revised 26 June 2014; accepted 12 July 2014

Copyright (C) 2014 by authors and Scientific Research Publishing Inc.

This work is licensed under the Creative Commons Attribution International License (CC BY).

http://creativecommons.org/licenses/by/4.0/

(c) (i) Open Access

\section{Abstract}

Four solanaceous plant species, namely hot pepper (Capsicum frutescens L.), potato (Solanum tuberosum L.), tobacco (Nicotiana tabacum L.) and tomato (Lycopersicon esculentum Miller) were anatomically screened for compatibility/incompatibility to field dodder (Cuscuta campestris Yuncker, Cuscutaceae). The development of field dodder haustorium within stem tissues of the studied solanaceous plants was found to depend on the latter's response to the former's penetration. In hot pepper and tobacco, which showed a positive response, the haustorium was well developed and its searching hyphae established connections with their vascular tissues. However, potato and tomato showed a negative response and acquired different defense mechanisms against the parasitism of field dodder. In both of them, the field dodder haustorium and/or its searching hyphae exhibited distorted appearance and failed to establish connection with their vascular tissues. Thus, the tested solanaceous plant species could be classified as either compatible (hot pepper and tobacco) or incompatible (potato and tomato) hosts to field dodder.

\section{Keywords}

Compatible or Incompatible Hosts, Field Dodder, Haustorium, Searching Hyphae, Solanaceous Plant Species

\section{Introduction}

Dodders (Cuscuta spp., Cuscutaceae) usually have extremely broad host ranges and can even be attached to dif- 
ferent hosts at once [1]. In this respect, field dodder (Cuscuta campestris Yuncker, Cuscutaceae) (FD) is known to parasitize a large number of plant species belonging to different families via modified roots known as haustoria. According to the definition of Kuijt [2], the haustorium is a modified root that forms a morphological and physiological link between the parasite and the host. In addition the haustorium of FD normally develops from a small group of meristematic cells situated above the contact cells of the parasite and pushes itself through these contact cells. Hence, it is inserted within the host tissues. Therefore, the development of the haustorium is controlled more or less by the response of the host tissues (negatively or positively) towards its intrusion into them. Anatomically, the haustoria of various FD species in different host plants have been investigated by a number of research workers e.g. [2]-[12]. The objectives of the present work were to screen through anatomical techniques the response of four solanaceous plant species, namely hot pepper (Capsicum frutescens L.), potato (Solanum tuberosum L.), tobacco (Nicotiana tabacum L.) and tomato (Lycopersicon esculentum Miller), to the parasitism of field dodder (Cuscuta campestris Yuncker, Cuscutaceae ) and accordingly to classify them as compatible or incompatible hosts.

\section{Materials and Methods}

Plant materials (samples of host shoots with attached FD shoots) were obtained from a pot experiment set to study the effect of FD on solanaceous crop species (hot pepper, potato, tobacco, tomato). The pots were placed in the Botanical Garden of the Faculty of Science and Technology, Omdurman Islamic University, Omdurman, Sudan, during November-March, 2011/2012. The plant materials were excised and treated for light microscopy according to the methods of Farah [10] and Berlynand and Miksche [13] with some modifications. The samples were fixed in F.A.A. (Formaldehyde, Acetic acid, Alcohol) of 1:1:18 ratio, dehydrated in gradual ethanol solutions ranging from $15 \%$ to $99.9 \%$, then treated in mixtures of absolute ethanol (99.9\%) and xylene in three different ratios, 3:1, 1:1, 1:3, respectively. The samples were infiltrated with xylene and embedded in paraffin wax. Sections (15 $\mu \mathrm{m}$ thick) were prepared using Bright 5040 type rotary microtome. They were stained with safranin and light green stains and mounted in Canada balsam. The stained sections were examined microscopically using an Olympus 1 - 12 Binocular Light Microscope. Then, they were sent to the laboratory of Botany, King Faisal University (Saudi Arabia) to perform microscopic photographs (micrographs). The micrographs were taken under 10× and 40× objective lenses using Leitz Laborlux 12 Microscope supplemented with VarioOrthmat (Camera system) for automatic photography.

\section{Results and Discussion}

The haustorium of the parasitic flowering plants is a specialized channel though which water and nutrients flow from the host to the parasite. In addition, it is the organ which embodies the very idea of parasitism [2]. The haustorium of FD is a wedge like organ which originates from superficial protuberances limited to the contact surface of the tight haustorial coils [4]. In the current study, it was found that the development of FD haustorium within tissues of its host plants was controlled by the response of the stem tissues of the host plants to the penetration and intrusion of the endophyte (the part of the haustorium inside the host) into them. In hot pepper, thehaustorium of FD was well developed and formed functional searching hyphae that established connections with its cortical parenchyma cells and phloem tissue (Figure 1), while in tobacco, the haustorial searching hyphae established connections with both phloem and xylem tissues (Figure 2). So, hot pepper and tobacco, manifisting positive response, were found to be compatible hosts to FD. However, tobacco showed more compatibility towards FD compared to hot pepper. Similar results about the susceptibility of hot pepper and tobacco to FD were reported by Farah and El-Hassan [9].

On the other hand, potato and tomato experienced different response towards the parasitism of FD viz. they were found to be incompatible hosts to FD. Potato showed hypertrophy against the penetration of the haustorium of FD into its stem tissues. The cortical cells of potato stem surrounding the haustorium of FD and its searching hyphae increased in size (i.e. acquired hypertrophy), a reaction which resulted in a distorted appearance of the endophyte and its isolation from the area of the host vascular tissues by blocking its intrusion and stopping the flow of nutrients from the host tissues, thus keeping it ill nourished (Figure 3). Likewise, tomato showed hypersensitivity against the intrusion of FD endophyte into its stem tissues. The cortical cells of tomato stem were damaged as a result of the intrusion of FD endophyte (Figure 4). Consequently the endophyte was exhibited distorted appearance and became functionless, perhaps because of lack of nourishment. Thus, it was isolated 


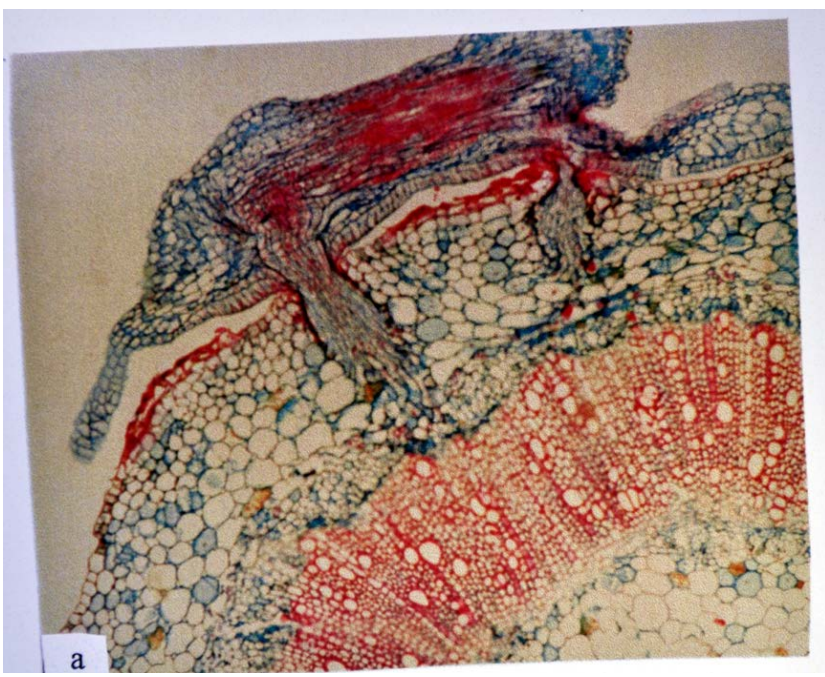

Figure 1. The haustorium searching hyphae of FD connected to the cortical parenchyma cells and phloem tissue of hot pepper stem $(\times 100)$.

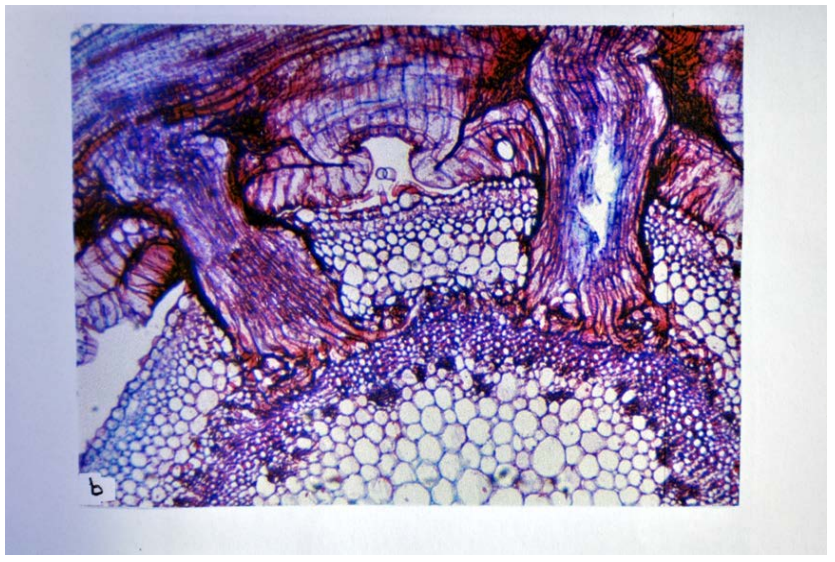

Figure 2. The haustorium searching hyphae of FD established connections with both phloem and xylem tissues of tobacco $(\times 100)$.

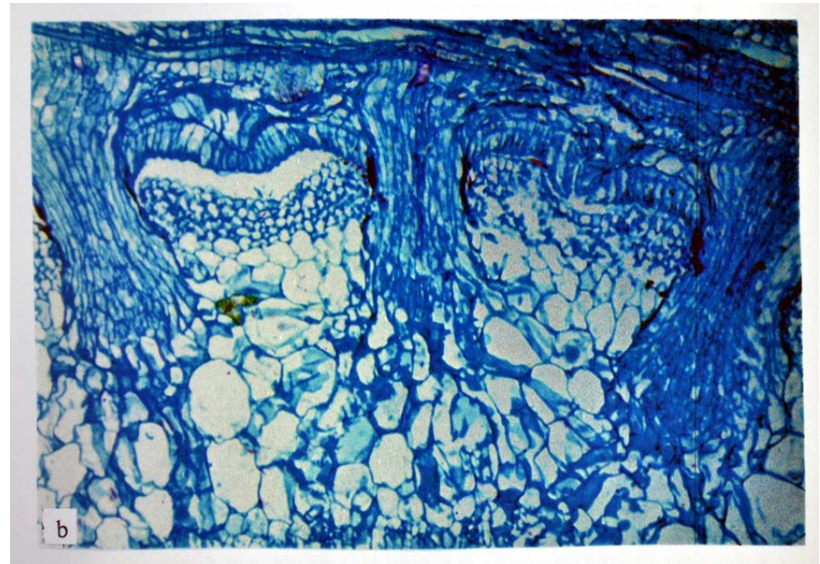

Figure 3. The cortical parenchyma cells of potato stem showing hypertrophy (enlargment) as a reaction against the intrusion of FD endophyte $(\times 100)$. 


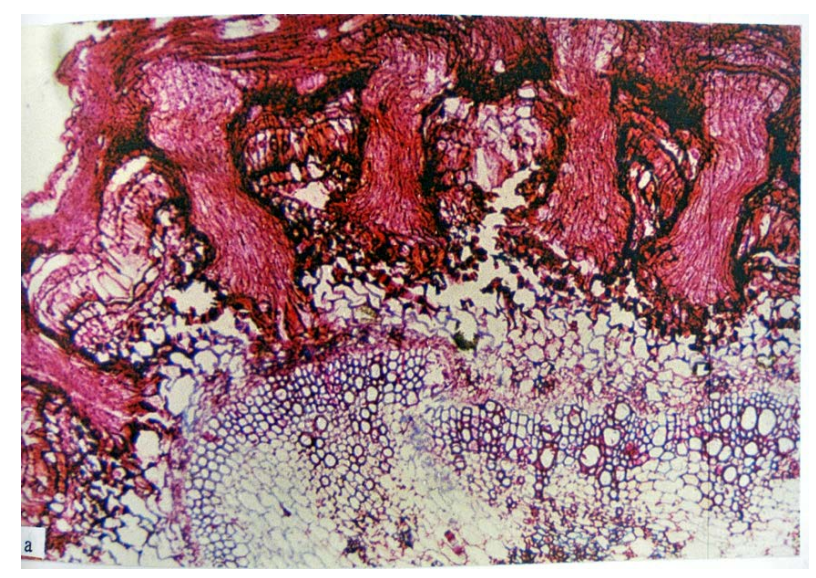

Figure 4. The cortical cells of tomato stem showing hypersensitivity (damage of cells as a reaction against the intrusion of FD endophyte $(\times 100)$.

from reaching the vascular tissues of tomato stem. In agreement with these findings are those reported by Farah and El-Hassan [9], Farah [10], Ihl and Mische [14] and Loffler et al. [15]. Hypertrophy and hypersensitivity by potato and tomato, respectively are anatomical stimulated defense mechanisms practiced by the two incompatible solanaceous hosts to resist the intrusive organs of the parasite (i.e. FD).

\section{Conclusion}

It could be concluded that compatible hosts are those in which the parasite's haustorial searching hyphae are well developed and established successful connections with their vascular tissues. On the other hand, the incompatible hosts are those in which the parasite's haustorial searching hyphae are not developed or developed but acquire distorted structures and fail to establish successful connections with their vascular tissues. For further research we suggest the use of antioxidative enzymes to measure the variation between compatible and incompatible plant species to FD.

\section{Acknowledgements}

Both authors contributed equally to this work. The authors thank members of the Department of Botany, Faculty of Science and Technology, Omdurman Islamic University, Omdurman, Sudan for the help with field work and part of the technical work. The authors thank members of the Botany Laboratory, King Faisal University, Saudi Arabia for help with part of the technical work.

\section{References}

[1] Dawson, J.H., Musselman, L.J., Wolswinker, P. and Dorr, I. (1994) Biology and Control of Cuscuta. Review of Weed Science, 6, 265-317.

[2] Kuijt, J. (1969) The Biology of Parasitic Flowering Plants. University of California Press, Berkeley and Los Angles.

[3] Kuijt, J. (1977) Haustoria of Phanerogamic Parasites. Annals Review of Phytopathology, 17, 19-11.

[4] Kuijt, J. (1991) The Haustorial Interphase. In: Ransom, J.K., Musselman, L.J., Worsham, A.D. and Parker, C., Eds., Proceedings of the 5th International Symposium of Parasitic Weeds, CIMMT, Nairobi, 1-5.

[5] Al-Menoufi, O.A. and Farag, S.A. (1996) Effect of Dodder (Cuscuta chinensis) on the Productivity of Some Varieties of Alfalfa (Medicago sativa). In: Moreno, M.T., Cubero, J.I., Berner, D., Joel, D., Musselman, L.J. and Parker, C., Eds., Advances in Plant Research, Proceedings of the 6th International Parasitic Weed Symposium, Cordoba, 394-398.

[6] Arnaud, M., Renaudin, S. and Fer, A. (1996) Investigation into the Cellular and Biochemical Events Involved in the Resistance of a Legume (Phaseolus vulgaris) to a Parasitic Higher Plant (Cuscuta reflexa). In: Moreno, M.T., Cubero, J.I., Berner, D., Joel, D., Musselman, L.J. and Parker, C., Eds., Advances in Plant Research, Proceedings of the 6th International Parasitic Weeds Symposium, Cordoba, 592-596.

[7] Dorr, I. (1987) The Haustorium of Cuscuta-New Structural Results. In: Weber, H.C. and Forsreuter, W., Eds., Para- 
sitic Flowering Plants, Proceedings of the 4th International Symposium of Parasitic Flowering Plants, Marburg, 163170.

[8] Joel, D.M., Losner-Goshan, D., Hershenhorn, J., Goldwasser, Y. and Assayag, A. (1996) The Haustorium and Its Development in Compatible and Resistant Hosts. In: Moreno, M.T., Cubero, J.I., Burner, D., Joel, D., Musselman, L.J. and Parker, C., Eds., Advances in Parasitic Plants Research, Proceedings of the 6th International Parasitic Weed Symposium, Cordoba, 531-541.

[9] Farah, A.F. and El-Hassan, G.M. (2002) Anatomical Mechanisms of Resistance to Field Dodder (Cuscuta campestris Yuncker) in Some Horticultural and Field Crops. University of Khartoum Journal of Agricultural Sciences, 1, 77-93.

[10] Farah, A.F. (2007) Resistance of Some Plant Species to Field Dodder (Cuscuta campestris Yuncker). African Crop Science Conference Proceedings, 8, 413-417.

[11] Farah, A.F. (2009) The Response of Two Legume Crops (Hyacinth Bean and Kidney Bean) to the Parasitism of Field Dodder (Cuscuta campestris Yuncker). In: Rubiales, D., Westwood, J. and Alugu, A., Eds., 10th World Congress on Parasitic Plants Proceedings, Kusadasi, 87.

[12] Tsivion, Y. (1979) Morphogenetic Sequences in the Formation of the Haustorium of Cuscuta campestris. In: Musselman, L.J., Worsham, A.D. and Eplee, R.E., Eds., Proceedings of the 2nd Symposium on Parasitic Weeds, North Carolina, 174-181.

[13] Berlynand, G.P. and Mische, J.P. (1976) Botanical Microtechnique and Cytochemistry. The Iowa State University Press, Ames.

[14] Ihl, B. and Mierch, I. (1996) Susceptibility and Resistance of Lycopersicon to Infection by Cuscuta. In: Moreno, M.T., Cubero, J.I., Berner, D., Joel, D., Musselman, L.J. and Parker, C., Eds., Advances in Plant Research, Proceedings of the 6th International Parasitic Weeds Symposium, Cordoba, 599-605.

[15] Loffler, C., Sahm, A., Czygan, F.C. and Proksch, P. (1996) Aspects of the Incompatible Host-Parasite Relationship of Tomato and Cuscuta. In: Moreno, M.T., Cubero, J.I., Berner, D., Joel, D., Musselman, L.J. and Parker, C., Eds., Advances in Plant Research, Proceedings of the 6th International Parasitic Weed Symposium, Cordoba, 581-598. 
Scientific Research Publishing (SCIRP) is one of the largest Open Access journal publishers. It is currently publishing more than 200 open access, online, peer-reviewed journals covering a wide range of academic disciplines. SCIRP serves the worldwide academic communities and contributes to the progress and application of science with its publication.

Other selected journals from SCIRP are listed as below. Submit your manuscript to us via either submit@scirp.org or Online Submission Portal.
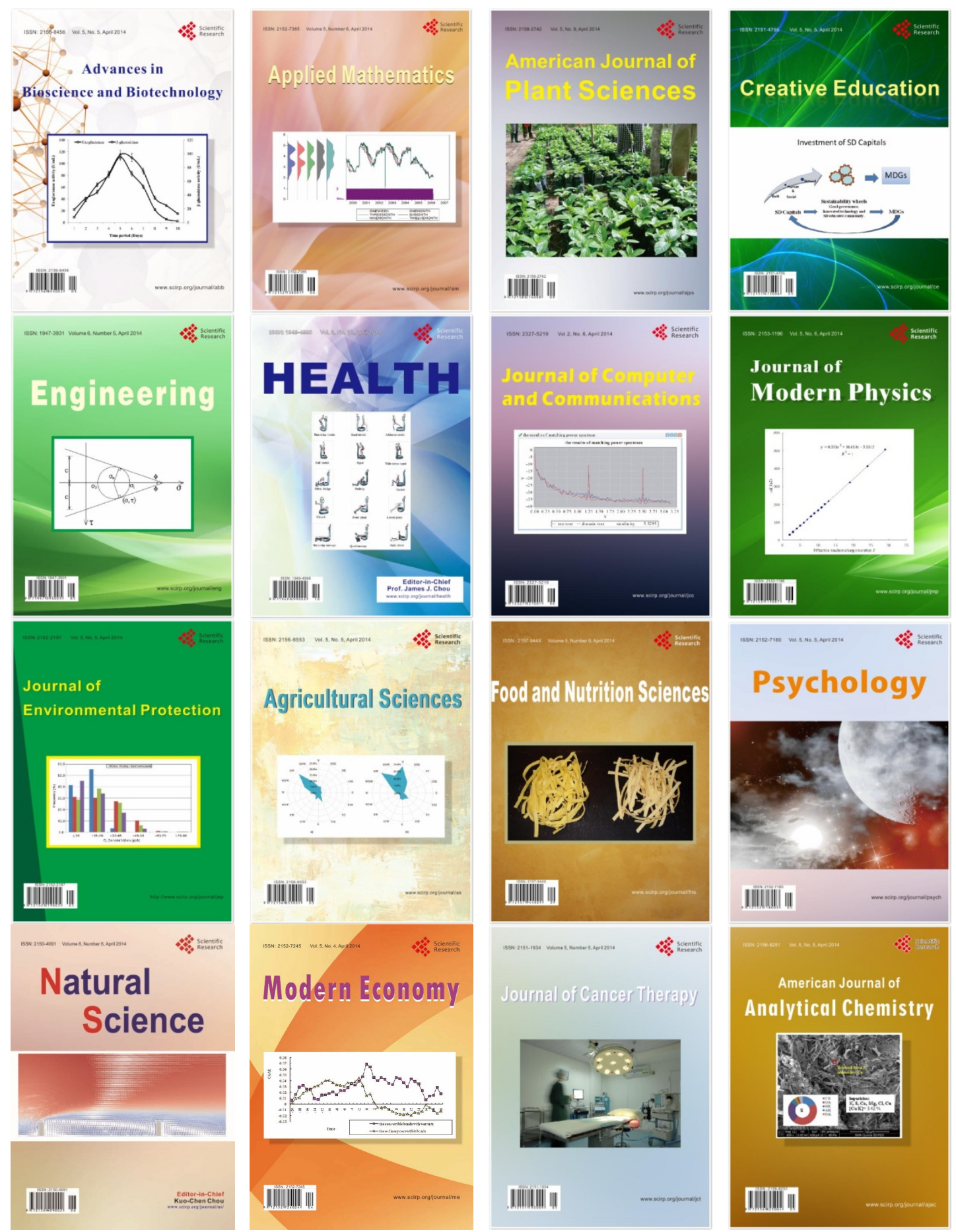